\begin{tabular}{c|c|c|}
\cline { 3 - 3 } CRITICAL & $\begin{array}{l}\text { Western Ghats } \\
\text { EARTNESTEM }\end{array}$ \\
Special Series
\end{tabular}

\title{
Fish fauna of Indrayani River, northern Western Ghats, India
}

\author{
Neelesh Dahanukar ${ }^{1}$, Mandar Paingankar ${ }^{2}$, Rupesh N. Raut ${ }^{3}$ \& Sanjay S. Kharat ${ }^{4}$ \\ ${ }^{1}$ Indian Institute of Science Education and Research, Sai Trinity, Garware Circle, Pune, Maharashtra 411021, India \\ ${ }^{2}$ Department of Zoology, University of Pune, Ganeshkhind, Pune, Maharashtra 411007, India \\ ${ }^{3}$ Department of Zoology, Elphinstone College, Mumbai, Maharashtra 400032, India \\ ${ }^{4}$ Department of Zoology, Modern College of Arts, Science and Commerce, Ganeshkindh, Pune, Maharashtra 411007, India. \\ Email: ${ }^{1}$ n.dahanukar@iiserpune.ac.in (corresponding author), ${ }^{2}$ mandarpaingankar@gmail.com, ${ }^{3}$ rupesh.raut@gmail.com, \\ ${ }^{4}$ kharat.sanjay@gmail.com
}

\begin{abstract}
The freshwater fish fauna of the Indrayani River, a northern tributary of the Krishna River system in the Western Ghats of India was studied. A total of 57 species of freshwater fish belonging to 18 families and 39 genera were recorded. However based on the previous literature it is possible that the Indrayan River harbours around 67 species. Out of the 57 species in the present collection, 12 are endemic to the Western Ghats while six are endemic to the Krishna River system. Neotropius khavalchor an endemic fish of the Krishna River system, was recorded for the first time from the northern tributaries. The fish fauna of the Indrayani River is threatened due to seven introduced species and anthropogenic activities such as deforestation leading to siltation, tourism, sand mining, over fishing and organic and inorganic pollution. Since the Indrayani River hosts endemic and threatened species, including Glyptothorax poonaensis, conservation measures to ensure habitat protection in the river are essential.
\end{abstract}

Keywords: Freshwater fish fauna, Indrayani River, Krishna River system, Threats.

Date of publication (online): 26 January 2012

Date of publication (print): 26 January 2012

ISSN $0974-7907$ (online) | 0974-7893 (print)

Editor: K. Rema Devi

Manuscript details:

Ms \# 02771

Received 25 April 2011

Final received 24 September 2011

Finally accepted 10 January 2012

Citation: Dahanukar, N., M. Paingankar, R.N. Raut \& S.S. Kharat (2012) Fish fauna of Indrayani River, northern Western Ghats, India. Journal of Threatened Taxa 4(1): 2310-2317.

Copyright: @ Neelesh Dahanukar, Mandar Paingankar, Rupesh N. Raut \& Sanjay S. Kharat 2012. Creative Commons Attribution 3.0 Unported License. JoTT allows unrestricted use of this article in any medium for non-profit purposes, reproduction and distribution by providing adequate credit to the authors and the source of publication.

Acknowledgements: We are thankful to Dr. R.M. Sharma, Officer-incharge, and Shrikant Jadhav, Zoological Survey of India, Western Regional Center, Akurdi, Pune, for encouragement and helpful discussion. The study was self funded. The CEPF-funded freshwater assessment of the Western Ghats encouraged us to publish this work. We duly acknowledge the help from CEPF for publication of this article.

OPEN ACGESS | FREE DOWNLOAD

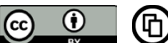

The Indrayani River originates in the northern Western Ghats of India at Kurwande Village $\left(18.731^{\circ} \mathrm{N} \& 73.382^{\circ} \mathrm{E}\right)$ near Lonawala, Pune District, Maharashtra. It is one of the tributaries of Bhima River, which in turn is a major tributary of the Krishna River system. In his seminal work on the fishes of the Deccan, Sykes (1839) described two species of freshwater fish from the Indrayani River. After more than 100 years, Suter (1944) recorded one more species from the Indrayani River at Kalumbre Village. A major study on the fish fauna of Indrayani River was carried out by Yazdani \& Mahabal (1976), which resulted in the collection of 34 species belonging to 10 families and 19 genera. These three studies account for hardly 37 species of freshwater fish, which seems an under representation when compared with fish fauna of other rivers such as Mula-Mutha with a record of 102 fish species (Kharat et al. 2003) and Pavna with a record of 59 fish species (Chandanshive et al. 2007), which are also tributaries of the Bhima River. Furthermore, the habitats along the Indrayani River have faced major alterations in the recent years due to increasing urbanization, industrialization and various recreational activities. Reassessment of the fish fauna and identifying the threats, so as to build baseline information for possible conservation action

This article forms part of a special series on the Western Ghats of India, disseminating the results of work supported by the Critical Ecosystem Partnership Fund (CEPF), a joint initiative of l'Agence Française de Développement, Conservation International, the Global Environment Facility, the Government of Japan, the MacArthur Foundation and the World Bank. A fundamental goal of CEPF is to ensure civil society is engaged in biodiversity conservation. Implementation of the CEPF investment program in the Western Ghats is led and coordinated by the Ashoka Trust for Research in Ecology and the Environment (ATREE). 


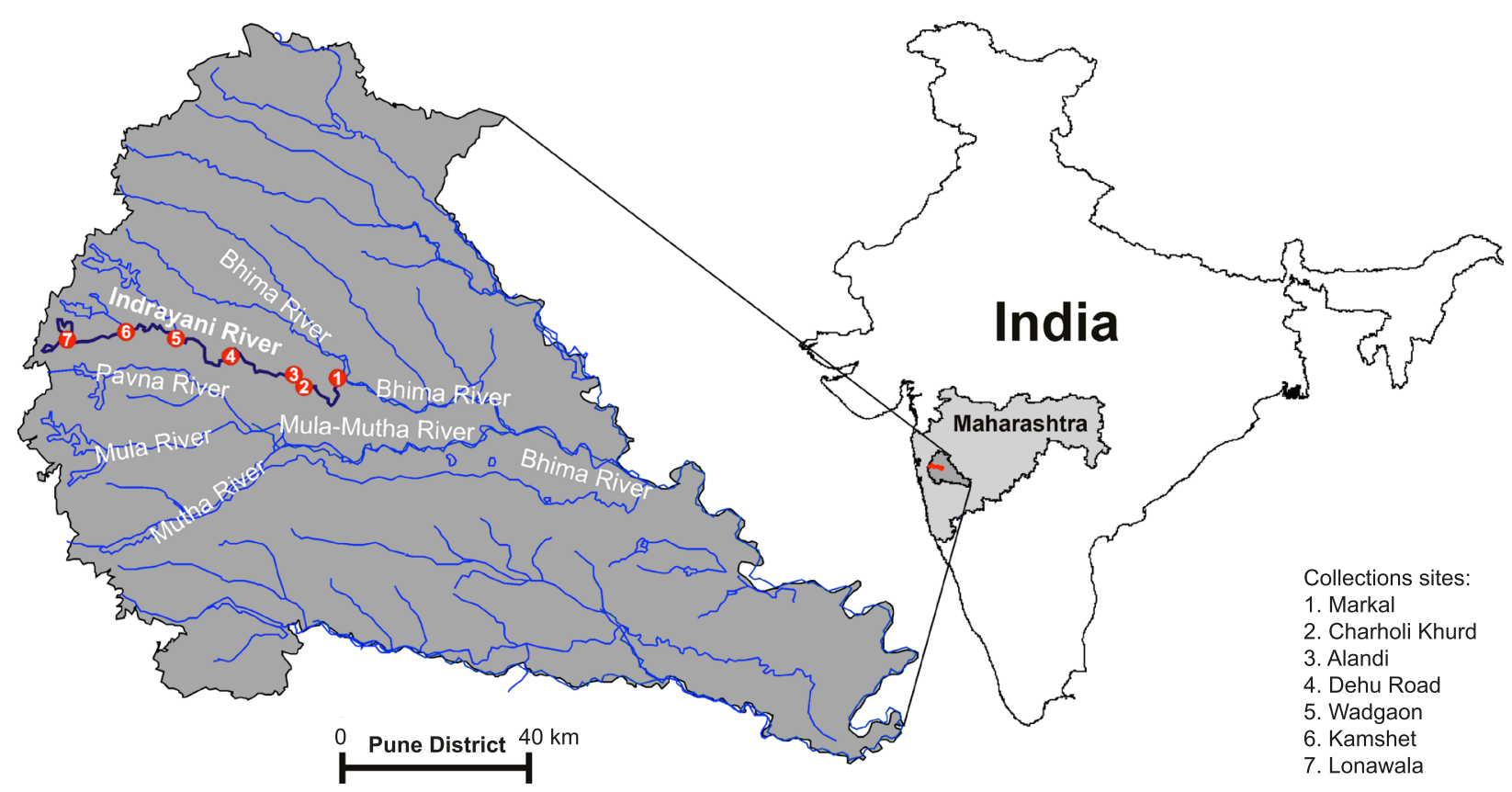

Figure 1. Indrayani River and the sampling locations.

plans are thus a priority. For the current study, we sampled the entire stretch of the Indrayani River to identify the current status and threats to the freshwater fish fauna of this region.

Fish were collected from local fisherman and local markets at Markal $\left(18.674^{\circ} \mathrm{N} \& 73.983^{\circ} \mathrm{E}\right)$, Charholi Khurd $\left(18.660^{\circ} \mathrm{N} \& 73.906^{\circ} \mathrm{E}\right)$, Alandi $\left(18.677^{\circ} \mathrm{N}\right.$ \& $\left.73.895^{\circ} \mathrm{E}\right)$, Dehu road $\left(18.719^{\circ} \mathrm{N} \& 73.764^{\circ} \mathrm{E}\right)$, Wadgaon $\left(18.754^{\circ} \mathrm{N} \& 73.653^{\circ} \mathrm{E}\right)$, Kamshet $\left(18.767^{\circ} \mathrm{N}\right.$ $\left.\& 73.551^{\circ} \mathrm{E}\right)$ and Lonawala $\left(18.753^{\circ} \mathrm{N} \& 73.432^{\circ} \mathrm{E}\right)$ located on the Indrayani River (Fig. 1) from May 2009 to April 2011. Fish were preserved in 4\% formaldehyde and identified using available literature (Jayaram 1991, 2010; Menon 1964, 1987, 1992; Talwar \& Jhingran 1991; Jayaram \& Dhas 2000; Jayaram \& Sanyal 2003). Collected fish specimens are deposited at the Museum of the Zoological Survey of India, Western Regional Center, Akurdi, Pune (accession numbers $\mathrm{P} / 2588$ to $\mathrm{P} / 2627$ ). Assuming that the fishing effort for a given type of net (gill net or drag net) was constant, the relative abundance of the fish was grossly categorized (for each type of net separately) into four categories, namely: abundant (76-100 \% of the total catch), common (51-75\% of the total catch), moderate $(26-50 \%$ of the total catch) and rare (1-25 $\%$ of the total catch).

We recorded a total of 57 species belonging to 18 families and 39 genera (Table 1). Of these, 12 species are endemic to the Western Ghats while five are endemic to the Krishna River system. Seven species that we collected were observed to be introduced into the Indrayani River. According to the abundance categories defined earlier there are 11 abundant, 14 common, 23 moderate and nine rare species. The list of species recorded by earlier studies on the Indrayani River is given in Table 2. Based on the previous literature and not considering two species, namely Schistura dayi and S. savona, which need taxonomic validation as they are restricted to central and northeastern India respectively, the total number of species in the Indrayani River can be summed up to 67 . However, out of these 67 species, Schismatorhynchos nukta is locally extirpated while Aplocheilus lineatus is probably locally extirpated from Indrayani River.

Sykes (1839) described two species, namely Schismatorhynchos nukta and Leuciscus chitul, from Indrayani River. We could not record S. nukta in our study and the species was also not recorded in an earlier study by Yazdani \& Mahabal (1976). Based on our discussions with the local fishermen, the species is locally extirpated from its type locality in Indrayani River. Ghate et al. (2002) suggested that the population of $S$. nukta is rapidly declining in the Krishna River system and suspected that pollution could be a major threat. Kharat et al. (2003) suggested that over fishing could be a driving force for local extinction of this 
Table 1. List of freshwater fish species recorded from Indrayani River in the present study.

\begin{tabular}{|c|c|c|c|c|c|c|c|}
\hline \multirow{2}{*}{ Family/Species ${ }^{a}$} & \multirow{2}{*}{ Abundance ${ }^{\mathrm{b}}$} & \multirow[b]{2}{*}{ Remarks $^{c}$} & \multirow{2}{*}{$\begin{array}{l}\text { IUCN } \\
\text { redlist } \\
\text { status }^{\mathrm{d}}\end{array}$} & \multirow{2}{*}{\begin{tabular}{|l} 
Schistura denisoni Day, 1867 \\
Cobitidae \\
\end{tabular}} & \multirow[t]{2}{*}{$\mathrm{C}$} & \multirow[b]{3}{*}{$\mathrm{D}$} & \multirow[t]{2}{*}{ LC } \\
\hline & & & & & & & \\
\hline \multicolumn{4}{|l|}{ Notopteridae } & $\begin{array}{l}\text { Lepidocephalichthys thermalis } \\
\text { (Valenciennes, 1846) }\end{array}$ & A & & LC \\
\hline Notopterus notopterus (Pallas, & C & & LC & \begin{tabular}{|l|} 
Bagridae \\
\end{tabular} & & & \\
\hline \multirow{2}{*}{\multicolumn{4}{|c|}{ Cyprinidae }} & Mystus bleekeri (Day, 1877) & $\mathrm{M}$ & & LC \\
\hline & & & & Mystus seengtee (Sykes, 1839) & $\mathrm{C}$ & & LC \\
\hline Catla catla (Hamilton, 1822) & $\mathrm{M}$ & $\mathrm{T}$ & & \multirow{2}{*}{$\begin{array}{l}\text { Mystus malabaricus (Jerdon, } \\
\text { 1849) }\end{array}$} & \multirow{2}{*}{ M } & \multirow[b]{2}{*}{ WGE } & \multirow{2}{*}{ NT } \\
\hline Cirrhinus fulungee (Sykes, 1839) & C & & LC & & & & \\
\hline Cirrhinus reba (Hamilton, 1822) & C & & LC & Rita gogra (Sykes, 1839) & $\mathrm{M}$ & & LC \\
\hline $\begin{array}{l}\text { Cirrhinus mrigala (Hamilton, } \\
\text { 1822) }\end{array}$ & M & $\mathrm{T}$ & & \begin{tabular}{|l} 
Sperata seenghala (Sykes, \\
1839 )
\end{tabular} & $\mathrm{M}$ & & LC \\
\hline Cyprinus carpio Linnaeus, 1758 & $M$ & $T$ & & Siluridae & & & \\
\hline $\begin{array}{l}\text { Gonoproktopterus curmuca } \\
\text { (Hamilton, 1807) }^{\mathrm{e}}\end{array}$ & A & WGE & EN & $\begin{array}{l}\begin{array}{l}\text { Ompok bimaculatus (Bloch, } \\
\text { 1794) }\end{array} \\
\end{array}$ & C & & NT \\
\hline Labeo ariza (Hamilton, 1807) & $\mathrm{R}$ & & LC & $\begin{array}{l}\text { Wallago attu (Bloch \& Schneider, } \\
\text { 1801) }\end{array}$ & $\mathrm{R}$ & & NT \\
\hline Labeo boggut (Sykes, 1839) & $\mathrm{R}$ & & LC & Schilbeidae & & & \\
\hline Labeo calbasu (Hamilton, 1822) & $\mathrm{M}$ & & LC & Neotropius khavalchor Kulkarni, & & & \\
\hline Labeo porcellus (Heckel, 1844) & $\mathrm{R}$ & WGE & LC & $\begin{array}{l}\text { Neotropius knavalcnor kuikarm, } \\
1952\end{array}$ & $\mathrm{R}$ & KRE & $\mathrm{DD}$ \\
\hline Labeo rohita (Hamilton, 1822) & $\mathrm{M}$ & $T$ & & Sisoridae & & & \\
\hline $\begin{array}{l}\text { Osteobrama cotio peninsularis } \\
\text { Silas, } 1952\end{array}$ & M & & $\mathrm{NE}$ & $\begin{array}{l}\text { Glyptothorax poonaensis Hora, } \\
1938\end{array}$ & $\mathrm{R}$ & $\begin{array}{l}\text { WGE, } \\
\text { KRE }\end{array}$ & EN \\
\hline Osteobrama neilli (Day, 1873) & $\mathrm{R}$ & WGE & LC & Claridae & & & \\
\hline $\begin{array}{l}\text { Osteobrama vigorsii (Sykes, } \\
\text { 1839) }\end{array}$ & c & & LC & $\begin{array}{l}\text { Clarias gariepinus (Burchell, } \\
\text { 1822) }\end{array}$ & M & 1 & \\
\hline \multirow{2}{*}{$\begin{array}{l}\text { Puntius amphibius } \\
\text { (Valenciennes, 1842) }\end{array}$} & \multirow{2}{*}{ A } & & \multirow{2}{*}{ DD } & \begin{tabular}{|l|} 
Heteropneustidae \\
\end{tabular} & & & \\
\hline & & & & $\begin{array}{l}\text { Heteropneustes fossilis (Bloch, } \\
1794 \text { ) }\end{array}$ & M & & LC \\
\hline $\begin{array}{l}\text { Puntius conchonius (Hamilton, } \\
\text { 1822) }\end{array}$ & $\mathrm{R}$ & & LC & \begin{tabular}{|l|} 
Belonidae \\
\end{tabular} & & & \\
\hline Puntius jerdoni (Day, 1870) & $\mathrm{R}$ & WGE & LC & Xenentodon cancila (Hamilton, & & & \\
\hline \multirow{2}{*}{$\begin{array}{l}\text { Puntius sarana subnasutus } \\
\text { (Valenciennes, 1842) }\end{array}$} & \multirow{2}{*}{ M } & \multirow{2}{*}{ WGE } & \multirow{2}{*}{$\mathrm{NE}$} & 1822) & M & & LC \\
\hline & & & & Poeciliidae & & & \\
\hline $\begin{array}{l}\text { Puntius sophore (Hamilton, } \\
\text { 1822) }\end{array}$ & A & & LC & Poecilia reticulata Peters, 1859 & $A$ & 1 & \\
\hline Puntius ticto (Hamilton, 1822) & A & & LC & Ambassidae & & & \\
\hline \multirow{2}{*}{ Rohtee ogilbii (Sykes, 1839) } & $M$ & WGE, & LC & \begin{tabular}{|l} 
Chanda nama Hamilton, 1822 \\
\end{tabular} & $\mathrm{C}$ & & LC \\
\hline & & KRE & & Parambassis ranga (Hamilton, & M & & 10 \\
\hline Amblypharyngodon mola & A & & LC & 1822) & IVI & & LU \\
\hline Salmophasia balookee (Sykes, & & & & \begin{tabular}{|l|} 
Cichlidae \\
Oreochromis mossambicus
\end{tabular} & & & \\
\hline 1839$)^{f}$ & M & & LC & (Peters, 1852) & A & 1 & \\
\hline Salmophasia boopis (Day, 1874) & A & WGE & LC & Gobiidae & & & \\
\hline $\begin{array}{l}\text { Salmophasia novacula } \\
\text { (Valenciennes, 1840) } \\
\end{array}$ & c & WGE & LC & \begin{tabular}{|l|} 
Glossogobius giuris (Hamilton, \\
1822 ) \\
\end{tabular} & $\mathrm{C}$ & & $\mathrm{NE}$ \\
\hline $\begin{array}{l}\text { Devario aequipinnatus } \\
\text { (McClelland, 1839) }\end{array}$ & c & & LC & \begin{tabular}{|l|} 
Channidae \\
\end{tabular} & & & \\
\hline Rasbora daniconius (Hamilton, & A & & LC & $\begin{array}{l}\text { Channa marulius (Hamilton, } \\
\text { 1822) }\end{array}$ & M & & LC \\
\hline \begin{tabular}{|l|}
$1822)$ \\
Crosecheilus of latius
\end{tabular} & & & & \begin{tabular}{|l|} 
Channa punctata (Bloch, 1793) \\
\end{tabular} & $\mathrm{C}$ & & LC \\
\hline $\begin{array}{l}\text { Crossocheilus cf. latius } \\
\text { (Hamilton, 1822) }\end{array}$ & c & & LC & \begin{tabular}{|l|} 
Mastecembalidae \\
\end{tabular} & & & \\
\hline Garra mullya (Sykes, 1839) & A & & LC & $\begin{array}{l}\text { Mastacembelus armatus } \\
\text { (Lacepède, 1800) }\end{array}$ & C & & LC \\
\hline
\end{tabular}

\begin{tabular}{|c|c|c|c|}
\hline \multicolumn{4}{|l|}{ Parapsilorhynchidae } \\
\hline $\begin{array}{l}\text { Parapsilorhynchus tentaculatus } \\
\text { (Annandale, 1919) }\end{array}$ & M & & LC \\
\hline \multicolumn{4}{|l|}{ Balitoridae } \\
\hline $\begin{array}{l}\text { Acanthocobitis mooreh (Sykes, } \\
\text { 1839) }{ }^{\mathrm{g}}\end{array}$ & $\mathrm{M}$ & & LC \\
\hline $\begin{array}{l}\text { Oreonectes evezardi (Day, } \\
\text { 1872) }\end{array}$ & M & & LC \\
\hline $\begin{array}{l}\text { Nemachilichthys rueppelli } \\
\text { (Sykes, 1839) }^{\mathrm{g}}\end{array}$ & M & $\begin{array}{l}\text { WGE, } \\
\text { KRE }\end{array}$ & LC \\
\hline $\begin{array}{l}\text { Noemacheilus anguilla } \\
\text { Annandale, } 1919\end{array}$ & M & $\begin{array}{l}\text { WGE, } \\
\text { KRE }\end{array}$ & LC \\
\hline
\end{tabular}

a - Taxonomic status as per Jayaram (2010);

b - Abundance categories: $\mathrm{A}=$ abundant, $\mathrm{C}=$ common, $\mathrm{M}=$ moderate, $\mathrm{R}=$ rare;

c - WGE $=$ Western Ghats endemic; KRE $=$ Krishna river system endemic; $T=$ transplanted; I = invasive; $D=$ unknown disease.

d - IUCN (2011). EN = Endangered, NT = Near Threatened, LC = Least Concern, NE $=$ Not Evaluated, DD $=$ Data Deficient. Statuses for introduced/transplanted species are not provided.

e - Gonoproktopterus kolus is considered as synonym of G. curmuca (Jayaram 2010). However, if they are proved to be different, then our species should be considered as G. kolus as per Jayaram (1991).

f - Replacement name for Salmophasia clupoides (Kottelat 1996)

$\mathrm{g}$ - Species spellings as per Eschmeyer \& Fricke (2011). 
Table 2. List of fishes recorded by earlier workers.

\begin{tabular}{|c|c|c|c|}
\hline Study & Species & Current taxonomic status & Remarks \\
\hline \multirow[b]{2}{*}{ Sykes (1839) } & Cyprinus nukta & Schismatorhynchos nukta & Species is locally extirpated \\
\hline & Leuciscus chitul & $\begin{array}{l}\text { Current status unknown. Doubtful synonym } \\
\text { of Amblypharyngodon mola in Day (1878) }\end{array}$ & Species needs further taxonomic studies \\
\hline Suter (1944) & Barbus (Tor) mussullah & Tor mussullah & \\
\hline \multirow{34}{*}{$\begin{array}{l}\text { Yazdani \& } \\
\text { Mahabal (1976) }\end{array}$} & Chela cachius & Chela cachius & \\
\hline & Danio aequipinnatus & Devario aequipinnatus & \\
\hline & Danio malabaricus & Devario malabaricus & \\
\hline & Rasbora daniconius & Rasbora daniconius & \\
\hline & Cirrihina fulungee & Cirrhinus fulungee & \\
\hline & Garra gotyla & Garra gotyla stenorhynchus & $\begin{array}{l}\text { Taxonomic status based on distribution of } \\
\text { the subspecies given in Jayaram (2010) }\end{array}$ \\
\hline & Garra mullya & Garra mullya & \\
\hline & Puntius amphibius & Puntius amphibius & \\
\hline & Puntius dorsalis & Puntius dorsalis & \\
\hline & Puntius kolus & Gonoproktopterus curmuca & \\
\hline & Puntius sarana & Puntius sarana subnasutus & $\begin{array}{l}\text { Taxonomic status based on distribution of } \\
\text { the subspecies given in Jayaram (2010) }\end{array}$ \\
\hline & Puntius ticto & Puntius ticto & \\
\hline & Osteobrama vigorsii & Osteobrama vigorsii & \\
\hline & Parapsilorhynchus tentaculatus & Parapsilorhynchus tentaculatus & \\
\hline & Lepidocephalus guntea & Lepidocephalus guntea & \\
\hline & Lepidocephalus thermalis & Lepidocephalus thermalis & \\
\hline & Noemacheilus anguilla & Noemacheilus anguilla & \\
\hline & Noemacheilus botia aurius & Acanthocobitis mooreh & \\
\hline & Noemacheilus dayi & Schistura dayi & Needs taxonomic validation \\
\hline & Noemacheilus denisoni & Schistura denisoni & \\
\hline & Noemacheilus evezardi & Oreonectes evezardi & \\
\hline & Noemacheilus savona & Schistura savona & Needs taxonomic validation \\
\hline & Noemacheilichthys rueppelli & Nemachilichthys rueppelli & \\
\hline & Mystus bleekeri & Mystus bleekeri & \\
\hline & Mystus cavasius & Mystus seengtee & \\
\hline & Mystus malabaricus & Mystus malabaricus & \\
\hline & Ompok bimaculatus & Ompok bimaculatus & \\
\hline & Glyptothorax lonah & Glyptothorax lonah & \\
\hline & Xenentodon cancila & Xenentodon cancila & \\
\hline & Aplocheilus lineatus & Aplocheilus lineatus & Species is probably locally extirpated \\
\hline & Channa orientalis & Channa gachua & \\
\hline & Channa punctatus & Channa punctatus & \\
\hline & Glossogobius giuris & Glossogobius giuris & \\
\hline & Mastacembelus armatus & Mastacembelus armatus & \\
\hline
\end{tabular}

species from Mula-Mutha Rivers of Pune. Both, over fishing and inorganic and organic pollution are common in Indrayani River and may have been the driving force for the local extirpation of $S$. nukta.
Nevertheless, we also suspect that competition created by introduced carps, such as Cirrhinus mrigala and Labeo rohita, may also have contributed to the loss of S. nukta. Currently, $S$. nukta is assessed as Endangered 
in the IUCN Red List of Threatened Taxa (Dahanukar 2010a).

Another species, Leuciscus chitul, described by Sykes (1839) from Indrayani River has problematic taxonomic status. Eschmeyer \& Fricke (2011) have included the species in their online Catalogue of Fishes but the current status of the fish is not mentioned. Day (1878) has considered L. chitul as a doubtful synonym of Amblypharyngodon mola. However, we think that the doubtful synonymy is invalid as the description of $L$. chitul does not apply to A. mola. We could not record any species from Indrayani River which could fit into the description of $L$. chitul given by Sykes (1839).

Suter (1944) recorded Tor mussullah from the Indrayani River. Even though we could not record this species and its allied species Tor khudree from the Indrayani River, both species are present in the Valvan reservoir on the Indrayani River at Lonawala where they are subjected to aquaculture.

Yazdani \& Mahabal (1976) recorded 34 species from Indrayani River out of which 10 species were not recorded in our current study. Of these 10 species, we are doubtful about the taxonomic identification of two species, namely Schistura dayi and S. savona. S. dayi is restricted to the Chota Nagpur plateau in central India (Jayaram 2010) and its occurrence in the Krishna River system is unlikely (Raghavan et al. 2010). Similarly, $S$. savona is restricted to northeastern India (Jayaram 2010). We think that Aplocheilus lineatus recorded by Yazdani \& Mahabal (1976) is probably locally extirpated from the Indrayani River, as we could not record a single specimen of this species during our investigation. Nevertheless, we could record abundant populations of Poecilia reticulata or Guppy fish introduced to the Indrayani River for the purpose of mosquito control. It has been suggested that $P$. reticulata is a strong competitor to $A$. lineatus, as both have the same larvivorous feeding habits, and has the capacity to affect the $A$. lineatus population negatively (Kharat et al. 2003; Wagh \& Ghate 2003). Therefore, we think that the introduction of $P$. reticulata could have been a major driving force for the decline in the population and possible local extirpation of

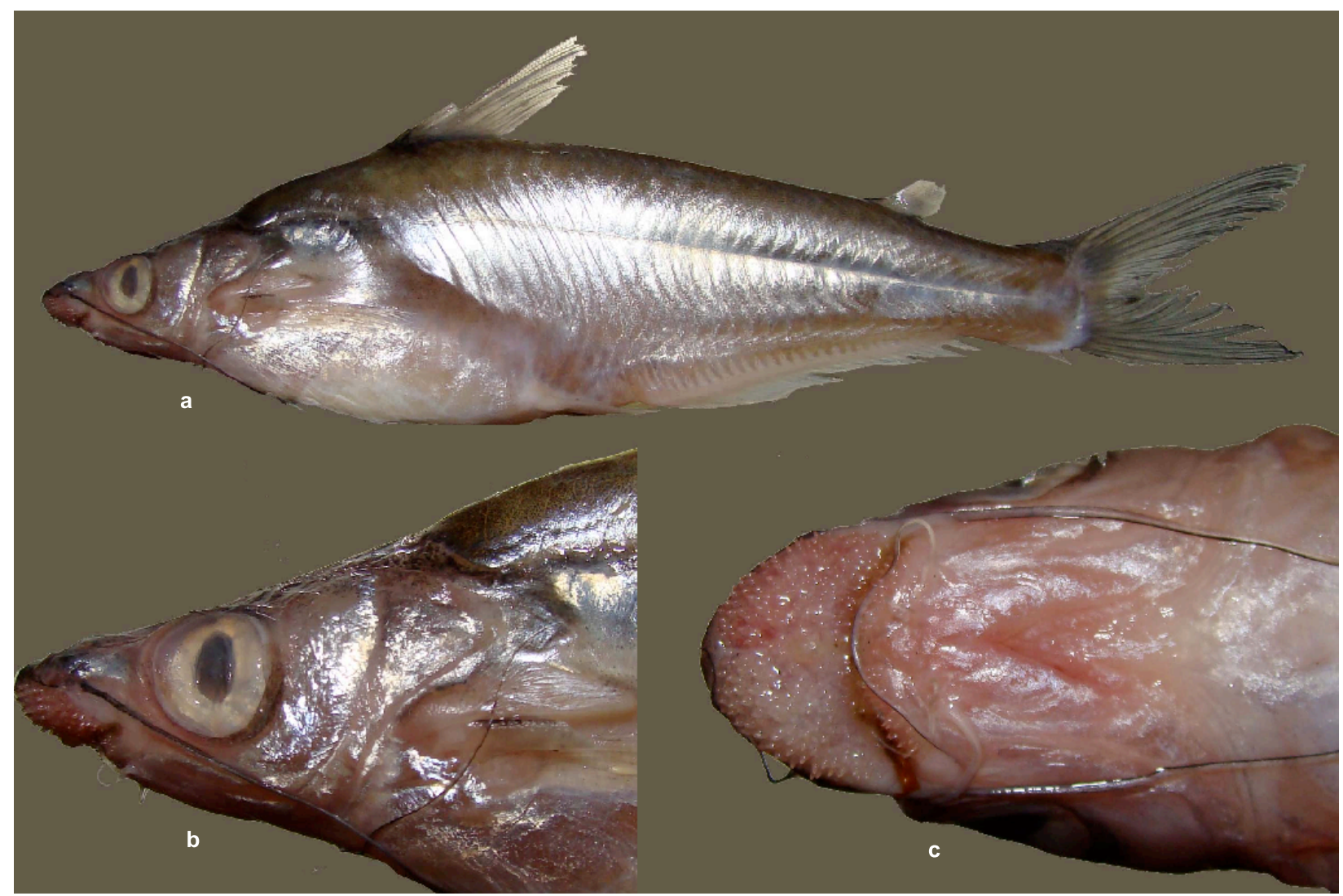

Image 1. Neotropius khavalchor collected from Kamshet with (a) details of its body, (b) head and (c) ventral side of the upper lip showing external teeth. 


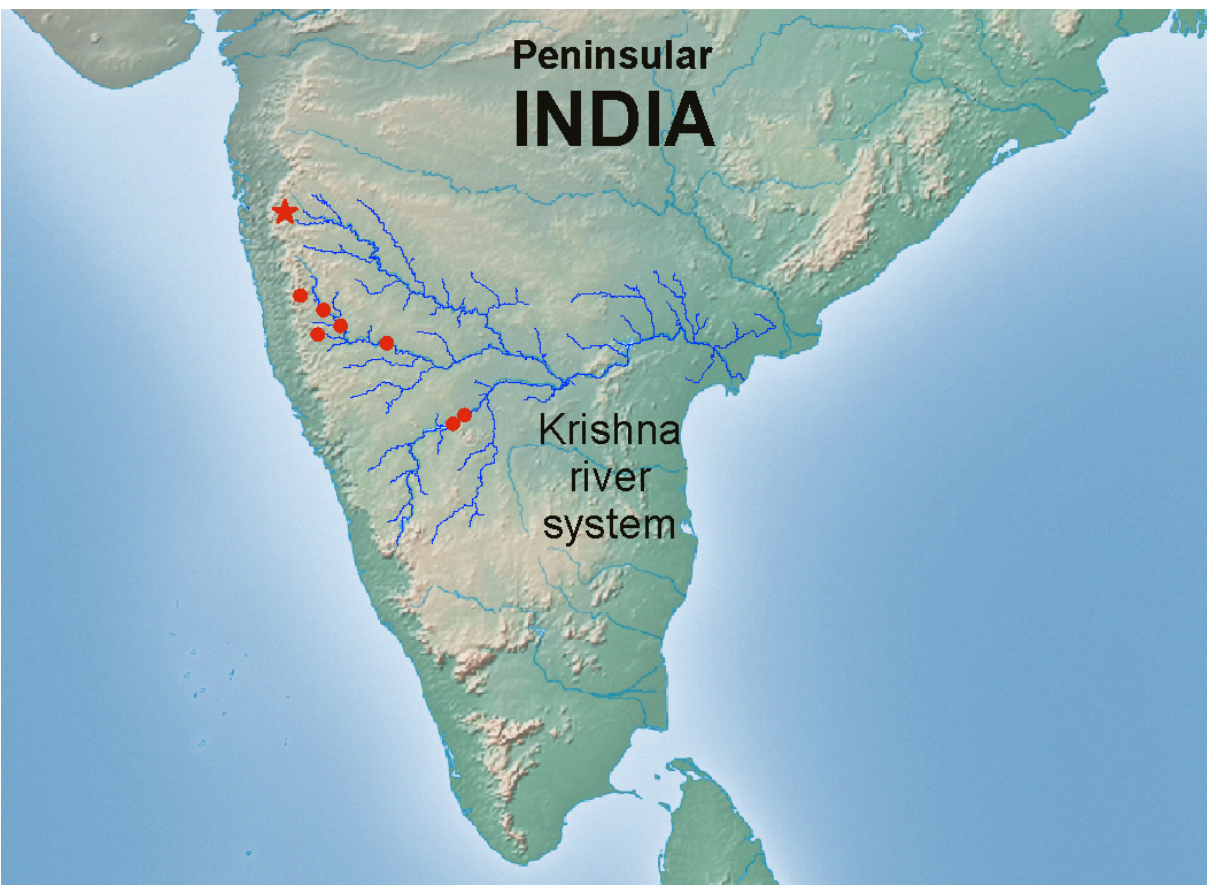

Image 2. Distribution of Neotropius khavalchor. Star indicates present record from Kamshet on Indrayani River.

Aplocheilus lineatus from Indrayani River.

We have recorded Neotropius khavalchor (Image 1) for the first time from the northern tributaries of the Krishna River system. N. khavalchor is a unique lepidophagous species (feeds on scales of other fishes and hence the local Marathi name Khavalchor [Khaval $=$ scales, Chor $=$ thief]) and is endemic to the Krishna River system (Menon 1999; Jayaram 2010). It is a very rare species and has been considered as threatened by Menon (2004) by suggesting that small changes in water quality is likely to have adverse effects and may result in the loss of this species. We recorded this species from Kamshet (Fig. 1 \& Image 2). The species is also known from Panchaganga River near Kolhapur (Kulkarni 1952; Kalawar \& Kelkar 1956), Krishna River near Islampur (Kulkarni 1952), Koyna River near Patan (Jadhav et al. 2011), Krishna River near Sangli (Jayaram 1995), Krishna River at Jamkhandi (Jayaram 1995), Tunga-Bhadra River (Shahnawaz \& Venkateshwarlu 2009) and in the Eastern Ghats of Andhra Pradesh (Devi \& Indra 2003). However, since there is little information about the population status, life history and ecology of this species, $N$. khavalchor is assessed as Data Deficient in the current IUCN Red List (Dahanukar 2010c).

Despite the fact that the Indrayani River hosts a number of endemic species and Endengered endemic species, such as Glyptothorax poonaensis
(Dahanukar 2010b; Dahanukar et al. 2011) the fish fauna of Indrayani River is under threat as a result of several anthropogenic interferences. We recorded seven introduced species (four transplanted and three invasive) from the Indrayani River (Table 1), which have been suggested as possible threats to the indigenous fish fauna (Kharat et al. 2003; Raghavan et al. 2008; Knight 2010). Other anthropogenic activities such as deforestation leading to siltation, recreational activities and sand mining are common in most of the stretches of the river. Such activities modify the specific habitat required by loaches belonging to family Balitoridae and Cobitidae and other hill stream fishes like Glyptothorax poonaensis (Dahanukar et al. 2011). Tourism in the upper stretches of the river leading to organic and inorganic pollution of smaller streams is another threat to the fishes of this region. The fish fauna of Indrayani River is also subjected to over fishing for consumption. Inorganic pollution of the river between Dehu Road to Markal due to industrial activities is another important threat to the fish fauna. Further, we observed an unidentified disease in Lepidocephalichthys thermalis in the upper stretches of the river near Lonawala where almost $70 \%$ of exploited individuals were affected. The nature of this disease, however, is still under study.

In conclusion, the Indrayani River hosts a number of freshwater fish species including globally threatened 
and endemic species of the Western Ghats. However, the fish fauna in this region is threatened due to several anthropogenic activities including introduced fish species, deforestation, over fishing, sand mining, recreational activities and organic and inorganic pollution. Since the fish fauna in this region also supports the livelihood of several economic classes there is an urgent need to understand the conservation priorities and to design and implement conservation action plans.

\section{REFERENCES}

Chandanshive, E.N., S.M. Kamble \& B.E. Yadav (2007). Fish fauna of Pavana river of Pune, Maharashtra. Zoos' Print Journal 22(5): 2693-2694.

Dahanukar, N. (2010a). Schismatorhynchos nukta. In: IUCN 2011. IUCN Red List of Threatened Species. Version 2011.1. $<$ www.iucnredlist.org> . Downloaded on 27 August 2011.

Dahanukar, N. (2010b). Glyptothorax poonaensis. In: IUCN 2011. IUCN Red List of Threatened Species. Version 2011.1. $<$ www.iucnredlist.org>. Downloaded on 27 August 2011.

Dahanukar, N. (2010c). Neotropius khavalchor. In: IUCN 2011. IUCN Red List of Threatened Species. Version 2011.1. $<$ www.iucnredlist.org>. Downloaded on 27 August 2011.

Dahanukar, N., M. Diwekar \& M. Paingankar (2011). Rediscovery of threatened and Western Ghats endemic Sisorid Catfish Glyptothorax poonaensis (Teleostei: Siluriformes: Sisoridae). Journal of Threatened Taxa 3(7): 1885-1898.

Day, F. (1878). The Fishes of India; Being A Natural History of the Fishes Known to Inhabit the Seas and Fresh Waters of India, Burma, and Ceylon. Volume 1. Bernard Quaritch, London, 778pp.

Devi, K.R. \& T.J. Indra (2003). An updated checklist of the fishes of the ichthyofauna of Eastern Ghats. Zoos' Print Journal 18(4): 1067-1070.

Eschmeyer, W.N. \& R. Fricke (eds.) (2011). Catalog of Fishes electronic version. http://research.calacademy.org/ ichthyology/catalog/fishcatmain.asp. Online version dated 29 March 2011. Downloaded on 22 April 2011.

Ghate, H.V., V.M. Pawar \& B.E. Yadav (2002). Note on cyprinoid fish Schismatorhynchos (Nukta) nukta (Sykes) from the Krishna drainage, Western Ghats. Zoos' Print Journal 17(7): 830-831.

IUCN (2011). IUCN Red List of Threatened Species. Version 2011.1. <www.iucnredlist.org>. Downloaded on 18 January 2012.

Jadhav, B.V., S.S. Kharat, R.N. Raut, M. Paingankar \& N. Dahanukar (2011). Freshwater fish fauna of Koyna River, northern Western Ghats, India. Journal of Threatened Taxa 3(1): 1449-1455.

Jayaram, K.C. \& A. Sanyal (2003). A Taxonomic Revision of the Fishes of the Genus Mystus Scopoli (Family: Bagridae). Occasional Paper No. 207. Records of the Zoological Survey of India, Kolkata, 136pp.

Jayaram, K.C. \& J.J. Dhas (2000). Revision of the Genus Labeo from Indian Region with A Discussion on its Phylogeny and Zoogeography. Occasional Paper No. 183. Records of the Zoological Survey of India, Kolkata, 143pp.

Jayaram, K.C. (1991). Revision of the Genus Puntius Hamilton from the Indian Region (Pisces: Cypriniformes, Cyprinidae, Cyprininae). Occasional Paper No. 135. Records of the Zoological Survey of India, Kolkata, 178pp.

Jayaram, K.C. (1995). The Krishna River System: A Bioresources Study. Occasional Paper No. 160. Records of Zoological Society of India, 167pp.

Jayaram, K.C. (2010). The Freshwater Fishes of the Indian Region. Second Edition. Narendra Publishing House, Delhi, 616pp.

Kalawar, A.G. \& C.N. Kelkar (1956). Fishes of Kolhapur. Journal of the Bombay Natural History Society 53(4): 669-679.

Kharat,S.S.,N.Dahanukar,R.Raut\&M.Mahabaleshwarkar (2003). Long term changes in freshwater fish species composition in north Western Ghats, Pune District. Current Science 84(6): 816-820.

Knight, J.D.M. (2010). Invasive ornamental fish: a potential threat to aquatic biodiversity in peninsular India. Journal of Threatened Taxa 2(2): 700-704.

Kottelat, M. (1996). Nomenclatural status of Cyprinus clupeoides Bloch, 1795 (Osteichthyes: Cyprinidae). Journal of South Asian Natural History 2(1): 61-62.

Kulkarni, C. (1952). A new genus of schilbeid catfishes from the Deccan. Records of the Indian Museum 49: 231-238.

Menon, A.G.K. (1964). Monograph of the cyprinid fishes of the genus Garra Hamilton. Memoirs of the Indian Museum 14(4): 173-260.

Menon, A.G.K. (1987). The Fauna of India and Adjacent Countries, Pisces, Vol-4, Teleostei-Cobitoidea, Part-1, Homalopteridae. Zoological Survey of India, Kolkata, $259 \mathrm{pp}$.

Menon, A.G.K. (1992). The Fauna of India and Adjacent Countries, Pisces, Vol-4, Teleostei-Cobitoidea, Part-2 Cobitidae. Zoological Survey of India, Kolkata, 113pp.

Menon, A.G.K. (1999). Check List - Fresh Water Fishes of India. Occasional Paper No. 175. Records of the Zoological Survey of India, Kolkata, 366pp.

Menon, A.G.K. (2004). Threatened Fishes of India and Their Conservation. Zoological Survey of India, Kolkata, 170pp.

Raghavan, R., A. Ali \& N. Dahanukar (2010). Schistura dayi. In: IUCN 2011. IUCN Red List of Threatened Species. Version 2011.1. <www.iucnredlist.org>. Downloaded on 27 August 2011.

Raghavan, R., G. Prasad, P.H. Anvar-Ali \& B. Pereira (2008). Exotic fish species in a global biodiversity hotspot: observations from river Chalakudy, part of Western Ghats, Kerala, India. Biological Invasions 10(1): 37-40.

Shahnawaz, A. \& M. Venkateshwarlu (2009). A checklist of 
fishes from the Tunga and Bhadra rivers, Karnataka, India with a special note on their biodiversity status. Current Biotica 3(2): 232-243.

Suter, M.J. (1944). New records of fish from Poona. Journal of the Bombay Natural History Society 44: 408-414.

Sykes, W.H. (1839). On the fishes of the Deccan. Proceedings of the General Meetings for Scientific Business of the Zoological Society of London 6: 157-165.
Talwar, P.K. \& A.G. Jhingran (1991). Inland Fishes of India and Adjacent Countries. Oxford-IBH Publishing Co. Pvt. Ltd., New Delhi, 1158pp.

Wagh, G.K. \& H.V. Ghate (2003). Freshwater fish fauna of the rivers Mula and Mutha, Pune, Maharashtra. Zoos 'Print Journal 18(1): 977-981.

Yazdani, G.M. \& A. Mahabal (1976). Fishes of Indrayani River. Biovigyanam 2: 119-121. 